The Fourth Trimester 
The publisher gratefully acknowledges the generous support of Famie Rosenthal Wolf, David Wolf, Rick Rosenthal, and Nancy Stephens as members of the Publisher's Circle of the University of California Press Foundation.

The publisher also gratefully acknowledges the generous support of the General Endowment Fund of the University of California Press Foundation. 


\section{The Fourth Trimester}

Understanding, Protecting, and

Nurturing an Infant through

the First Three Months

Susan Brink

ㄸ

UNIVERSITY OF CALIFORNIA PRESS

Berkeley Los Angeles London 
University of California Press, one of the most distinguished university presses in the United States, enriches lives around the world by advancing scholarship in the humanities, social sciences, and natural sciences. Its activities are supported by the UC Press Foundation and by philanthropic contributions from individuals and institutions. For more information, visit www.ucpress.edu.

University of California Press

Berkeley and Los Angeles, California

University of California Press, Ltd.

London, England

(C) 2013 by Susan Brink

Library of Congress Cataloging-in-Publication Data

Brink, Susan (Susan Frances)

The fourth trimester : understanding, protecting, and nurturing an infant through the first three months / Susan Brink.

p. $\mathrm{cm}$.

Includes bibliographical references and index.

ISBN 978-0-520-26712-I (cloth : alk. paper)

I. Infants-Development. 2. Infants-Care. 3. Newborn infants-

Development. 4. Newborn infants-Care. I. Title.

$\mathrm{HQ}_{774 .} \mathrm{B}_{755} 2013$

$649^{\prime} .122-\mathrm{dc} 23$

2012013037

Manufactured in the United States of America

$\begin{array}{llllllllll}\text { 20 } & \text { I9 } & \text { I8 } & \text { I7 } & \text { I6 } & \text { I5 } & \text { I4 } & \text { I3 } \\ \text { IO } & 9 & 8 & 7 & 6 & 5 & 4 & 3 & 2 & \text { I }\end{array}$

In keeping with a commitment to support environmentally responsible and sustainable printing practices, UC Press has printed this book on Rolland Enviroioo, a 100\% postconsumer fiber paper that is FSC certified, deinked, processed chlorine-free, and manufactured with renewable biogas energy. It is acid-free and EcoLogo certified. 
To Max, Makayla, Maggie, Ariana, Carissa, and Molly

And in loving memory of Nancy 
This page intentionally left blank 